PATTINGALLOANG

(C) Jurnal Pemikiran Pendidikan dan Penelitian Kesejarahan

\title{
Pengaruh Model Pembelajaran Talking Stick Terhadap Hasil Belajar Peserta Didik Pada Mata Pelajaran Sejarah Kelas X di SMK Grafika Yayasan Lektur
}

\author{
Bunga Octaveanry Nagara ${ }^{1}$, Lelly Qodariah ${ }^{2}$ Jumardi $^{3}$ \\ Prodi Pendidikan Sejarah Fakultas Keguruan dan Ilmu Pendidikan UHAMKA \\ ${ }^{1}$ bunga.nagara@gmail.com
}

\begin{abstract}
Abstrak
Penelitian ini bertujuan untuk mengetahui pengaruh model pembelajaran talking stick terhadap hasil belajar peserta didik pada mata pelajaran sejarah kelas X di SMK Grafika Yayasan Lektur. Metode penelitian yang digunakan adalah metode penelitian kuantitatif eksperimen. Sampel yang digunakan dalam penelitian ini yaitu kelas XA sebagai kelas eksperimen dan kelas XB sebagai kelas kontrol. Pada uji validitas instrumen menggunakan korelasi biserial dengan 25 butir soal pilihan ganda dengan 15 butir soal valid an 10 butir soal yang tidak valid. Teknik analisis data yang digunakan adalah uji normalitas, uji homogenitas dan uji hipotesis menggunakan uji t. Hasil penelitian menunjukkan bahwa: (1) terdapat perbedaan hasil belajar yang diberi perlakuan menggunakan model pembelajaran talking stick lebih tinggi daripada hasil belajar yang diberi perlakuan menggunakan model pembelajaran konvensional, dari analisis data diperoleh rata-rata kelas eksperimen 87,16 dan kelas kontrol 66,85 , (2) hasil pengujian hipotesis yang diperoleh $t_{\text {hitumg }}>t_{\text {tanel }}$ yaitu $2,107>2,002$ pada taraf signifikan $\alpha=0,05$. Hal tersebut berarti hipotesis dalam penelitian ini dapat diterima dan dinyatakan bahwa terdapat pengaruh model pembelajaran talking stick terhadap hasil belajar peserta didik pada mata pelajaran sejarah kelas X di SMK Grafika Yayasan Lektur. Kesimpulannya bahwa terdapat pengaruh dari model pembelajaran talking stick terhadap hasil belajar peserta didik pada mata pelajaran sejarah kelas X di SMK Grafika Yayasan Lektur.
\end{abstract}

Kata kuncr. model pembelajaran talking stick, hasil belajar

\begin{abstract}
This study aims to determine the effect of the talking stick learning model on student learning outcomes in class X history subjects at the SMK Grafika Foundation for Literature. The research method used was an experimental quantitative research method. The sample used in this study is class XA as an experimental class and class $\mathrm{XB}$ as a control class. In the validity test the instrument uses biserial correlation with 25 multiple choice questions with 15 valid items and 10 invalid items. Data analysis techniques used were normality test, homogeneity test and hypothesis testing using $\mathrm{t}$ test. The results showed that: (1) there were differences in learning outcomes that were treated using the talking stick learning model higher than learning outcomes that were treated using conventional learning models, from the analysis of the data obtained an experimental class average of 87.16 and a control class 66,85 , (2) the results of testing the hypothesis obtained tcouml $>$ table is $2.107>2.002$ at a significant level $\alpha=0.05$. This means that the hypothesis in this study can be accepted and it is stated that there is an effect of the talking stick learning model on student learning outcomes in class $\mathrm{X}$ history subjects at SMK Grafika Literature Foundation. The conclusion that there is an influence of the talking stick learning model on student learning outcomes in classs X history subjects at SMK Grafika Literature Foundation.
\end{abstract}

Keywords: talking stick learning model, learning outcomes

A. Pendahuluan

Pendidikan berperan penting dalam pengembangan sumber daya manusia, sehingga isi dan prosesnya perlu disesuaikan dengan kemajuan ilmu pengatahuan dan kebutuhan masyarakat (Amir, 2016: 1). Pemerintah merumuskan dalam undang-undang Republik Indonesia No. 20 tahun 2003 tentang Sistem 
Pendidikan Nasional menjelaskan bahwa pendidikan dilakukan untuk mendapatkan tujuan yang diharapkan bersama yaitu:

"Pendidikan nasional berfungsi mengembangkan kemampuan dan membentuk watak serta peradaban bangsa yang bermartabat dalam rangka mencerdaskan kehidupan bangsa, bertujuan untuk berkembangnya potensi peserta didik agar menjadi manusia yang beriman dan bertakwa kapada Tuhan Yang Maha Esa, berakhlak mulia, sehat, berilmu, cakap, kreatif, mandiri, dan menjadi warga negara yang demokratis serta bertanggung jawab".

Menurut Siregar (2015: 101) usaha untuk meningkatkan hasil belajar peserta didik dapat dilakukan dengan mulai menggunakan model dan metode pembelajaran yang tepat dan lebih bervariasi dalam penyampain suatu materi pelajaran. Hal tersebut guru dapat menggunakan serta memanfaatkan sumber belajar dengan masksimal sehingga peserta didik menjadi tertarik dalam kegiatan belajar di kelas.

Hasil belajar merupakan proses terjadinya perubahan pada peserta didik selama dan setelah proses belajar dilaksanakan. Keberhasilan mengajar juga ditinjau dari guru yakni dilihat dari memilih bahan ajar serta model pembelajaran yang digunakan dalam kelas untuk menciptakan suasana yang menyenangkan, aktif, kondusif. Namun dengan demikian keberhasilan tidak hanya dilihat dari guru melainkan pada peserta didik juga yakni ada rasa keinginan untuk aktif bertanya seperti dapat mengemukakan pendapat ketika ditanya oleh guru maupun ketika berdiskusi.

Tidak jarang ditemukan bahwa dalam pelaksanaan pembelajaran yang dilakukan oleh guru masih belum menerapkan model pembelajaran yang bervariasi sehingga hal ini menyebabkan peserta didik kurang maksimal terhadap materi yang disampaikan terutama dalam mata pelajaran sejarah. Menurut Agung \& Wahyuni (2013: 55) menyatakan bahwa sejarah adalah mata pelajaran yang menanamkan pengetahuan, sikap, dan nilai-nilai mengenai proses perubahan dan perkembangan masyarakat Indonesia dan dunia dari masa lampau hingga kini. Oleh karena itu sejarah merupakan salah satu mata pelajaran yang masih diajarkan di jenjang pendidikan.

Namun fakta yang terjadi di lapangan bagi peserta didik bahwa mata pelajaran sejarah adalah pelajaran yang membosankan bahkan beberapa peserta didik tidak mau memperhatikan dan bertanya, karena guru yang mengajarkan cenderung menggunakan model pembelajaran konvensional dan tidak berubah. Model pembelajaran konvensional digunakan karena materi sejarah yang dipaparkan begitu banyak serta jam pelajaran yang terbatas menyebabkan guru untuk memilih menggunakan model ini sehingga peserta didik merasa didongengi yang akhirnya ngantuk dan tertidur di kelas. Seharusnya guru mengevaluasi teknik pembelajaran yang digunakannya dengan begitu para peserta didik dapat menjadi aktif serta tertarik ketika pembelajaran sejarah sedang berlangsung.

Peran guru dalam kegiatan belajar mengajar harus bisa dalam memilih model pembelajaran apa yang akan digunakan sehingga pembelajaran yang akan dilaksanakan dapat berjalan dengan efektif, efisien, aktif, menyenangkan dan kondusif. Hasil belajar peserta didik juga dipengaruhi oleh model pembelajaran yang digunakan guru.

Dengan demikian model pembelajaran menjadi penting karena dapat memberikan kepada peserta didik pemahaman materi yang lebih baik. Menurut Joice\& Weil dalam Suhanji (2016: 99) model pembelajaran adalah suatu pola atau rencana yang sudah direnakan sedemikian rupa dan digunakan untuk menyusun kurikulum, mengatur materi pelajaran, dan memberi petunjuk kepada pengajar di kelasnya.

Model pembelajaran diperlukan karena dapat membuat peserta didik lebih aktif serta mampu membuat peserta didik menjadi tidak jenuh dalam materi yang akan diajarkan guru sehingga hasil belajar dapat lebih baik bahkan meningkat. Berkaitan dengan hasil belajar peserta didik pada mata pelajaran sejarah yang masih tergolong rendah untuk mengatasi masalah hasil belajar guru dapat menerapkan model 
pembelajaran talking stick ini karena pembelajaran dengan talking stick mendorong peserta didik untuk berani mengemukakan pendapat.

Talking stick yang dimaksudkan adalah permainan melalui tongkat dalam pembelajaran di kelas dalam permainan ini peserta didik menyanyikan lagu yang sudah disepakati bersama dan peserta didik yang memegang tongkat tersebut harus menjawab pertanyaan yang akan diberikan guru. Dengan pembelajaran ini memberikan peserta didik rasa tanggung jawab karena harus menjawab pertanyaan yang diberikan walaupun nantinya akan dibantu oleh peserta didik yang lain.

Dari hasil pra penelitian yang dilakukan bahwa dalam pembelajaran guru belum menerapkan model pembelajaran ketika mengajar. Pembelajaran yang dilakukan hanya dengan cara konvensional sehingga menyebabkan peserta didik merasa bosan dan menjadi kurang menarik hal tersebut akan berdampak pada hasil belajar peserta didik. Dengan demikian model pembelajaran talking stick cocok diterapkan pada mata pelajaran sejarah karena saat pembelajaran sejarah peserta didik tidak hanya diam saja melainkan adanya interaksi timbal balik yang dilakukan baik dari peserta didik maupun guru.

Berdasarkan uraian diatas peneliti melakukan penelitian dengan judul "Pengaruh Model Pembelajaran Talking Stick Terhadap Hasil Belajar Peserta Didik Pada Mata Pelajaran Sejarah Kelas X Di SMK Grafika Yayasan Lektur"

\section{B. Hasil dan Pembahasan}

\section{Deskripsi Data}

Penelitian ini dilaksanakan di SMK Grafika Yayasan Lektur pada kelas X. Peserta didik yang dijadikan sampel sebanyak 2 kelas yaitu kelas kontrol dan eksperimen dengan jumlah 59 orang, yakni kelas kontrol pada kelas XB berjumlah 25 orang dan kelas eksperimen pada kelas XA berjumlah 34 orang.

Instrumen penelitian yang sudah dibuat maka perlu diuji cobakan sebelum diberikan kepada kelas kontrol dan kelas eksperimen. Tes diuji coba pada kelas lain yaitu diluar kelas kontrol dan eksperimen. Instrumen yang akan diberikan sebanyak 25 butir pilihan ganda. Dari 25 butir soal yang disediakan terdapat 15 butir soal yang dinyatakan valid dan 10 butir soal yang tidak valid. Sedangkan pada hasil pengujian reliabilitas diperoleh rhitung $=0,71$ yang termasuk kedalam kategori reliabilitas tinggi.

Ketika uji coba sudah dilakukan maka selanjutnya dilakukan penelitian. Penelitian yang dilakukan di kelas X SMK Grafika Yayasan Lektur menggunakan model pembelaran talking stick di kelas eksperimen sedangkan pembelajaran konvensional di kelas kontrol.

Hasil Pre Test dan Post Test pada Kelas Kontrol

Berdasarkan penelitian yang sudah dilakukan maka diperoleh nilai peserta didik melalui pre test dan post test. Berikut di bawah ini tabel distribusi frekuensi:

Tabel 1.1 :Distribusi Frekuensi Data Pre Test Kelas Kontrol

\begin{tabular}{|c|c|c|}
\hline Interval Kelas & Frekuensi & $\begin{array}{c}\text { Frekuensi } \\
\text { relatif (\%) }\end{array}$ \\
\hline $53-58$ & 4 & $12 \%$ \\
\hline $59-64$ & 8 & $24 \%$ \\
\hline $65-70$ & 10 & $29 \%$ \\
\hline $71-76$ & 8 & $24 \%$ \\
\hline $77-82$ & 3 & $9 \%$ \\
\hline $83-88$ & 1 & $3 \%$ \\
\hline Jumlah & 34 & $100 \%$ \\
\hline
\end{tabular}

Berdasarkan tabel di atas bahwa jumlah peserta ddidik yang memiliki skor nilai antara 2026 sebesar $15 \%$, yang memiliki skor nilai antara 27-33 sebesar 21\%, yang memiliki 34-40 sebesar $24 \%$, yang memiliki skor nilai antara 41-47 sebesar 0\%, yang memiliki skor nilai antara 48-54 sebesar 29\%, yang memiliki skor nilai antara 5561 sebesar $12 \%$. Dapat dilihat data distribusi dari kelas kontrol pada histogram berikut ini: 
Gambar 1.2 Histogram Data Pre Test Kelas Kontrol

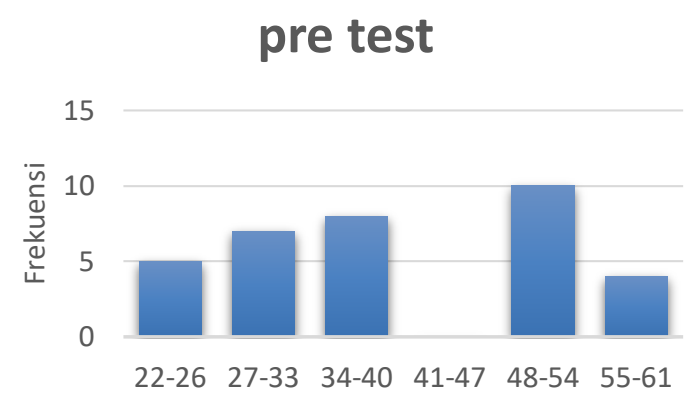

Setelah diketahui nilai pretest dari kelas control yang diberi perlakuan dengan menggunakan model pembelajaran konvensional maka selanjutnya diberikan post test dan dapat dilihat pada tabel berikut ini:

Tabel 1.3 Distribusi Frekuensi Data Post Test

\begin{tabular}{|c|c|c|}
\hline $\begin{array}{c}\text { Interval } \\
\text { Kelas }\end{array}$ & Frekuensi & $\begin{array}{c}\text { Frekuensi relatif } \\
\text { (\%) }\end{array}$ \\
\hline $20-26$ & 5 & $15 \%$ \\
\hline $27-33$ & 7 & $21 \%$ \\
\hline $34-40$ & 8 & $24 \%$ \\
\hline $41-47$ & 0 & $0 \%$ \\
\hline $48-54$ & 10 & $29 \%$ \\
\hline $55-61$ & 4 & $12 \%$ \\
\hline Jumlah & 34 & $100 \%$ \\
\hline
\end{tabular}

Kelas Kontrol

Berdasarkan tabel berikut bahwa jumlah peserta didik yang memiliki skor nilai antara 5358 sebesar $12 \%$, yang memiliki skor nilai antara 59-64 sebesar 24\%, yang memiliki 65-70 sebesar $29 \%$, yang memiliki skor nilai antara 71-76 sebesar $24 \%$, yang memiliki skor nilai antara 77 82 sebesar $9 \%$, yang memiliki skor nilai antara 77-82 sebesar $3 \%$.

Dapat dilihat data distribusi dari kelas kontrol pada histogram berikut ini:

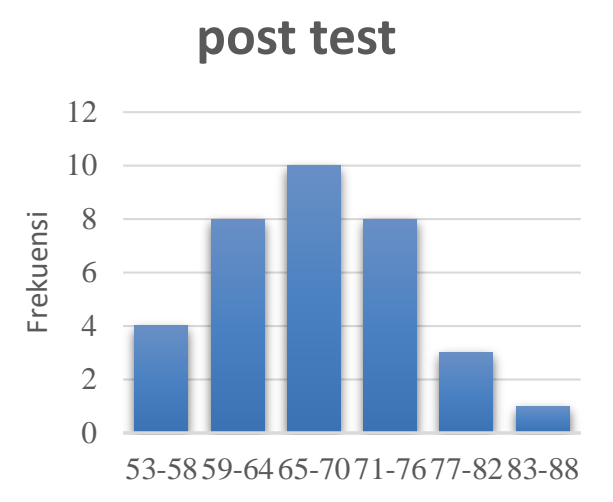

Hasil Pre Test dan Post Test pada Kelas Eksprimen

Berdasarkan penelitian yang sudah dilakukan maka diperoleh nilai peserta didik melalui pre test dan post test. Berikut tabel distribusi frekuensi:

Tabel 1.3: Distribusi Frekuensi Data Pre Test Kelas Eksperimen

\begin{tabular}{|c|c|c|}
\hline $\begin{array}{c}\text { Interval } \\
\text { Kelas }\end{array}$ & Frekuensi & $\begin{array}{c}\text { Frekuensi relatif } \\
\text { (\%) }\end{array}$ \\
\hline $20-26$ & 1 & $4 \%$ \\
\hline $27-33$ & 6 & $24 \%$ \\
\hline $34-40$ & 6 & $24 \%$ \\
\hline $41-47$ & 0 & $0 \%$ \\
\hline $48-54$ & 8 & $32 \%$ \\
\hline $55-61$ & 4 & $16 \%$ \\
\hline Jumlah & 25 & $100 \%$ \\
\hline
\end{tabular}

Berdasarkan tabel di atas bahwa jumlah peserta ddidik yang memiliki skor nilai antara 2026 sebesar 4\%, yang memiliki skor nilai antara 27-33 sebesar 24\%, yang memiliki 34-40 sebesar $24 \%$, yang memiliki skor nilai antara 41-47 sebesar 0\%, yang memiliki skor nilai antara 48-54 sebesar 32\%, yang memiliki skor nilai antara 5561 sebesar $16 \%$. Dapat dilihat data distribusi dari kelas eksperimen pada histogram berikut ini: 
Gambar 1.3: Histogram Data Pre Test Kelas Eksperimen

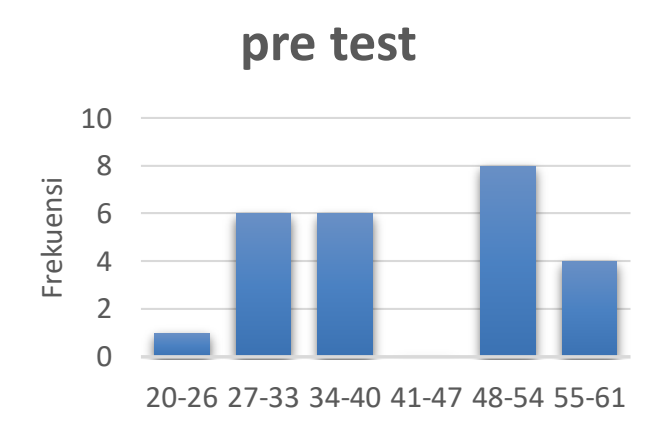

Setelah diketahui nilai pretest dari kelas eksperimen yang diberi perlakuan dengan menggunakan model pembelajaran talking stick maka selanjutnya diberikan post test dan dapat dilihat pada tabel berikut ini:

Tabel 1.4 : Distribusi Frekuensi Data Post Test Kelas Eksperimen

\begin{tabular}{|c|c|c|}
\hline Interval Kelas & Frekuensi & $\begin{array}{c}\text { Frekuensi } \\
\text { relatif (\%) }\end{array}$ \\
\hline & 2 & $8 \%$ \\
\hline $78-82$ & 6 & $24 \%$ \\
\hline $83-87$ & 7 & $28 \%$ \\
\hline $88-92$ & 0 & $0 \%$ \\
\hline $93-97$ & 8 & $32 \%$ \\
\hline $98-100$ & 2 & $8 \%$ \\
\hline Jumlah & 25 & $100 \%$ \\
\hline
\end{tabular}

Berdasarkan tabel tersebut bahwa jumlah peserta ddidik yang memiliki skor nilai antara 7377 sebesar $8 \%$, yang memiliki skor nilai antara 78 82sebesar 24\%, yang memiliki 83-87 sebesar 28\%, yang memiliki skor nilai antara 88-92sebesar $0 \%$, yang memiliki skor nilai antara 93-97sebesar $32 \%$, yang memiliki skor nilai antara 98-100 sebesar 8\%. Dapat dilihat data distribusi dari kelas eksperimen pada histogram berikut ini:

Gambar 1.4: Histogram Data Post Test Kelas Eksperimen

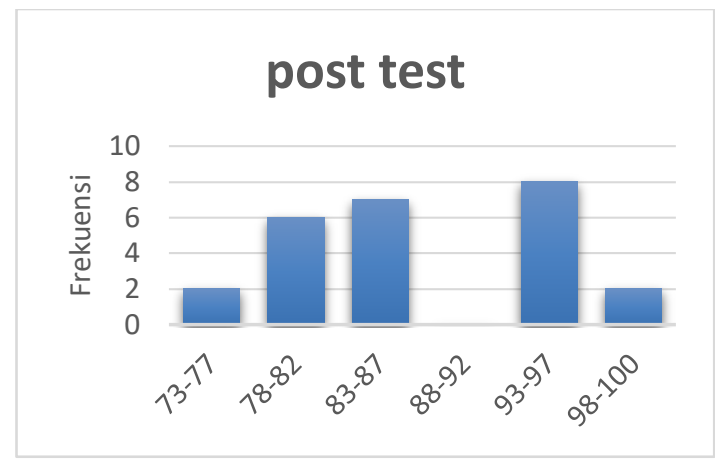

\section{Pengujian Persyaratan Analisis}

\section{Uji Normalitas}

Uji normalitas digunakan untuk mengetahui apakah data pre test dan post test pada peserta didik memiliki distribusi yang normal atau tidak. Untuk menguji normalitas menggunakan rumus liliefors yang diperoleh data sebagai berikut:

a. Pre Test

1) Nilai Pre Test Kelas Kontrol

Berdasarkan perhitungan uji normalitas pre test dapat disimpulkan bahwa seluruh sampel pada kelas kontrol untuk nilai pre test berasal dari populasi yang berdistribusi normal. Hal tersebut diperoleh karena Lhitung < Ltabel pada taraf signifikan $\alpha=0,05$. Perhitungan uji normalitas untuk nilai pre test. Perhitungan di atas Lhitung diperoleh dari harga yang paling besar sehingga Lhitung sebesar 0,145 dan Ltabel $=0,150$ pada taraf signifikan 0,05 . Hal ini menunjukkan bahwa Lhitung $<$ Ltabel yaitu $0,145<0,150$ maka dapat disimpulkan bahwa populasi berdistribusi normal.

2) Nilai Pre Test Kelas Eksperimen

Berdasarkan perhitungan uji normalitas pre test dapat disimpulkan bahwa seluruh sampel pada kelas eksperimen untuk nilai pre test berasal dari populasi yang berdistribusi normal. Hal tersebut diperoleh karena Lhitung < Ltabel pada taraf signifikan $\alpha=0,05$. Perhitungan uji normalitas untuk nilai pre test $\mathrm{L}$ hitung diperoleh dari harga yang paling besar sehingga Lhitung sebesar 0,156 dan Ltabel $=0,173$ pada taraf signifikan 0,05. Hal ini menunjukkan bahwa Lhitung $<$ Ltabel yaitu $0,156<0,173$ maka dapat disimpulkan bahwa populasi berdistribusi normal.

b. Post Test

1) Nilai Post Test Kelas Kontrol 
Berdasarkan perhitungan uji normalitas post test dapat disimpulkan bahwa seluruh sampel pada kelas kontrol untuk nilai post test berasal dari populasi yang berdistribusi normal. Hal tersebut diperoleh karena Lhitung < Ltabel pada taraf signifikan $\alpha=0,05$.

L hitung diperoleh dari harga yang paling besar sehingga Lhitung sebesar 0,144 dan Ltabel $=0,150$ pada taraf signifikan 0,05. Hal ini menunjukkan bahwa Lhitung<Ltabel yaitu 0,144 $<0,150$ maka dapat disimpulkan bahwa populasi berdistribusi normal.

\section{Nilai Post Test Kelas Eksperimen}

Berdasarkan perhitungan uji normalitas post test dapat disimpulkan bahwa seluruh sampel pada kelas kontrol untuk nilai post test berasal dari populasi yang berdistribusi normal. Hal tersebut diperoleh karena Lhitung < Ltabel pada taraf signifikan $\alpha=0,05$. Perhitungan uji normalitas untuk nilai post test dapat dilihat tabel dibawah ini:

Lhitung diperoleh dari harga yang paling besar sehingga Lhitung sebesar 0,154 dan Ltabel $=0,173$ pada taraf signifikan 0,05. Hal ini menunjukkan bahwa Lhitung $<$ Ltabel yaitu 0,154<0,173 maka dapat disimpulkan bahwa populasi berdistribusi normal.

Uji Homogenitas

Uji homogenitas dilakukan untuk mencari apakah sampel penelitian berasal dari varians yang sama atau homogen pada penelitian ini menggunakan taraf signifikan $\alpha=0,05$.

Uji Homogenitas Pre Test

Dapat dilihat dari perhitungan pada lampiran 6 maka uji homogenitas di dapat data sebagai berikut:

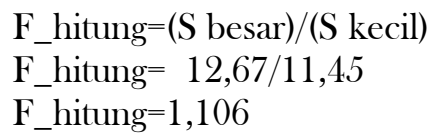

Setelah didapat Fhitung $=1,106$ dan Ftabel dengan taraf signifikan 0,05 maka diperoleh Fhitung $<$ Ftabel yakni $1,106<1,922$. Maka dapat dikatakan bahwa data dari kedua sampel untuk pre test adalah homogen atau berasal dari varians yang sama.
Uji Homogenitas Post Test

Berdasarkan pengujian data yang terdapat pada lampiran 6 maka uji homogenitas mendapat data sebagai berikut:

$$
\text { F_hitung }=(\mathbf{S} \text { besar }) /(\mathrm{S} \text { kecil })
$$

F_hitung $=8,47 / 7,39$

F_hitung $=1,146$

Setelah didapat Fhitung $=1,146$ dan Ftabel dengan taraf signifikan 0,05 maka diperoleh Fhitung $<$ Ftabel yakni $1,146<1,922$. Dapat disimpulkan bahwa data dari kedua sampel untuk post test adalah homogen atau berasal dari varians yang sama.

\section{Pengujian Hipotesis}

Setelah melakukan uji persyaratan analisis maka selanjutnya melakukan pengujian hipotesis penelitian. Pengujian hipotesis ini dilakukan agar mengetahui ada tidaknya pengaruh dari model pembelajaran talking stick terhadap hasil belajar peserta didik pada mata pelajaran sejarah kelas X di SMK Grafika Yayasan Lektur. Pengujian ini dilakukan di kelas kontrol dan eksperimen yang sebelumnya sudah dilakukan pre test untuk mengetahui kedua kelas tersebut mempunyai kemampuan yang sama atau tidak. Hasil dari perhitungan data post test peserta didik dapat dilihat pada lampiran 8 .

Dengan demikian taraf signifikan 0,05 dan dk $=\mathrm{n} 1+\mathrm{n} 2-2=25+34-2=57$ sehingga ttabel $=2,002$ dan thitung $=2,107$ maka diperoleh tahitung > ttabel yaitu 2,107>2,002. Hal tersebut berarti hipotesis diterima sehingga menyatakan bahwa terdapat pengaruh model pembelajaran talking stick terhadap hasil belajar peserta didik pada mata pelajaran sejarah kelas X di SMK Grafika Yayasan Lektur.

\section{Hasil Pengujian}

Penelitian ini dilakukan di SMK Grafika Yayasan Lektur untuk mengetahui pengaruh model pembelajaran talking stick terhadap hasil belajar peserta didik pada mata pelajaran sejarah. Penelitian ini dilaksanakan di kelas $\mathrm{X}$ dengan jumlah 75 peserta didik yang terdiri dari 3 kelas diantanya kelas XA dengan jumlah 25 peserta didik, XB dengan jumlah 35 peserta didik dan kelas XC dengan jumlah 15 peserta didik. Sampel yang diambil yaitu kelas XA sebagai kelas eksperimen yang diberi perlakuan dengan menggunakan model pembelajaran talking stick 
sedangkan kelas XB sebagai kelas kontrol yang diberi perlakuan dengan menggunakan pembelajaran konvensional.

Teknik pengumpulan data melalui pre test dan post test pada kedua kelas. Intrumen penelitian yang sudah dibuat maka perlu diuji cobakan sebelum diberikan kepada kelas kontrol dan kelas eksperimen. Tes diuji coba pada kelas lain yaitu diluar kelas kontrol dan eksperimen. Instrumen yang akan diberikan sebanyak 25 butir soal pilihan ganda. Dari hasil uji coba instrumen terdapat 15 butir soal yang dinyatakan valid yakni nomor 1,3,4,5,6,7,8,11,12,13,15,17,18,23 dan 25. Sedangkan yang dinyatakan tidak valid terdapat 10 butir soal. Kemudian untuk hasil uji reliabilitas instrumen sebesar 0,71 yang termasuk kedalam kategori reliabilitas tinggi.

Proses pelaksanaan penelitian pada masingmasing kelas sebanyak 3 kali pertemuan dengan waktu penelitian dari bulan September sampai bulan Oktober. Materi yang diajarkan pada penelitian ini yakni peradaban Indonesia zaman praaksara dengan sub-subnya yang terdiri dari perkembangan bumi dan munculnya makhluk hidup, jenis-jenis manusia purba, asal usul nenek moyang bangsa Indonesia dan corak kehidupan manusia zaman praaksara dengan alokasi waktu 3 x 45 menit.

Pelaksanaan pembelajaran di kelas XB pada kelas kontrol menggunakan model pembelajaran konvensional. Dalam pembelajaran ini berupa penjelasan dari guru dan tanya jawab. Untuk mengetahui kemampuan awal peserta didik maka diberikan pre test yakni tes yang diberikan sebelum materi pembelajaran dimulai. Setelah peserta didik menerima penjelasan materi yang diajarkan guru maka selajutnya guru memberikan tes akhir yaitu dengan post test. Post test ini bertujuan untuk mengetahui bagaimana kemampuan peserta didik setelah diberikan perlakuan dengan model konvensional.

Kemudian kelas XA pada kelas eksperimen menggunakan model pembelajaran talking stick. Sebelum pembelajaran dimulai diberikan pre test untuk mengetahui kemampuan awal tiap peserta didik. Pada model pembelajaran ini terlebih dahulu guru menjelaskan tujuan pembelajaran yang kemudian peserta didik membentuk 5 kelompok, sebelum melakukan pembelajaran talking stick tiap kelompok membuat peta konsep terlebih dahulu untuk memahami materi apa yang nantinya akan dibahas, peserta didik mendengarkan penjelasan materi dari guru setelah peserta didik mendengarkan materi yang telah disampaikan kemudian peserta didik diberi waktu untuk mendiskusikan materi pembelajaran, setelah selesai berdiskusi peserta didik dipersilahkan menutup sumber belajarnya, kemudian guru mengambil tongkat serta memberikan kepada salah satu anggota kelompok dan menyanyikan lagu sesuai dengan kesepakatan dan tongkat tersebut bergilir, peserta didik yang memegang tongkat harus menjawab pertanyaan yang diberikan guru begitu seterusnya sampai anggota kelompok lain mendapat giliran.

Penerapan model pembelajaran talking stick peserta didik didorong untuk berani mengemukakan pendapatnya ketika pertanyaan diberikan kepadanya walaupun nantinya akan dibantu oleh peserta didik yang lain. Setelah diberikan perlakuan pada kelas eksperimen maka hal yang sama dengan kelas kontrol diberikan tes akhir yakni post test untuk melihat pengaruh model pembelajaran talking stick. Dalam pembelajaran di kelas dengan menggunakan model pembelajaran ini peserta didik merasa antusias dan senang dengan penggunaan talking stick dalam pembelajaran sejarah karena bagi peserta didik penggunaan model ini berbeda dengan model pembelajaran yang sebelumnya yang hanya menggunakan model pembelajaran konvensional.

Hasil dari kelas kontrol dengan model konvensional jika dilihat dari lampiran 5 menyatakan bahwa nilai pre test pada salah satu responden sebesar 20 dan nilai pre test sebesar 53 hal tersebut mengalami kenaikan nilai sebesar 33. Sedangkan pada kelas eksperimen dengan model talking stick dari salah satu responden pada nilai pre test sebesar 20 dan nilai post test sebesar 73 hal ini mengalami kenaikan nilai yang meningkat sebesar 53 sehingga dapat dilihat bahwa dengan menggunakan model pembelajaran talking stick menyebabkan hasil belajar peserta didik mengalami kenaikan yang signifikan jika dibandikan dengan menggunakan model konvensional.

Berdasarkan pre test dan post test yang dilakukan pada kelas kontrol dan kelas eksperimen maka nilai pre test kelas kontrol memperoleh rata-rata sebesar 40,29 dengan standar deviasi 12,67 dan kelas ekperimen 43,20 
dengan standar deviasi 11,45. Sedangkan nilai post test untuk kelas kontrol memperoleh ratarata sebesar 66,85 dengan standar deviasi 8,48 dan kelas eksperimen 87,16 dengan standar deviasi 7,39.

Dapat dilihat bahwa pada kelas eksperimen pre test 43,20 dan post test 87,16 hal tersebut meningkat pada nilai post test karena pada pre test belum adanya perlakuan dan setelah diberikan perlakuan model pembelajaran talking stick terdapat pengaruh nilai rata-rata pada post test kelas eksperimen. Dan kelas kontrol rata-rata pre test 40,29 dan post test 66,85 dari post test masing-masing kelas terdapat peningkatan dari pada nilai pre test namun pada kelas kontrol tidak begitu meningkat jika dibandingan dengan kelas eksperimen karena pada kelas kontrol menggunakan model pembelajaran konvensional yang berupa ceramah penjelasan guru dan tanya jawab.

Hal ini menunjukkan terdapat peningkatan di kelas eksperimen terhadap hasil belajar peserta didik pada model pembelajaran talking stick. Penggunaan model ini dapat membantu peserta didik dalam pembelajaran sejarah karena adanya timbal balik yang dilakukan baik dari peserta didik maupun guru. Dilihat dari hasil belajar kelas kontrol bahwa rata-rata nilai masih rendah karena peserta didik merasa bosan dan kurang menarik dalam penyampaian materi tersebut.

Nilai-nilai peserta didik yang telah diperoleh dilakukan pengujian persyaratan analisis. Dari uji tersebut didapatkan bahwa data berdistribusi normal dan homogeny. Kemudian uji hipotesis untuk mengetahui ada tidaknya pengaruh model pembelajaran talking stick terhadap hasil belajar peserta didik pada mata pelajaran sejarah kelas X di SMK Grafika Yayasan Lektur. Berdasarkan pengujian hipotesis dengan menggunakan uji t dengan taraf signifikan 0,05 maka diperoleh hasil thitung > ttabel yakni 2,107>2,002. Dengan demikian bahwa hipotesis diterima hal tersebut berarti ada pengaruh model pembelajaran talking stick terhadap hasil belajar peserta didik pada mata pelajaran sejarah kelas X di SMK Grafika Yayasan Lektur.

Berdasarkan hipotesis yang teruji maka hipotesi ini didukung dengan teori K. Brahim dalam Ahmad Susanto yang menyatakan hasil belajar diartikan sebagai tingkat keberhasilan peserta didik dalam mempelajari materi pelajaran di sekolah yang dinyatakan dalam skor yang diperoleh dari hasil tes mengenai sejumlah materi pelajaran. Oleh karena itu dalam kelas ekperimen kegiatan pembelajaran diberi perlakuan model pembelajaran talking stick pada mata pelajaran sejarah hasil belajar peserta didik meningkat dibandingkan dengan kelas kontrol.

\section{Kesimpulan}

Penelitian ini betujuan untuk mengetahui pengaruh model pembelajaran talking stick terhadap hasil belajar peserta didik pada mata pelajaran sejarah kelas $\mathrm{X}$ di SMK Grafika Yayasan Lektur. Berdasarkan dari data hasil penelitian maka ditarik kesimpulan sebagai berikut:

Hasil dari penelitian menunjukan bahwa hasil belajar peserta didik setelah diberi perlakuan dengan model pembelajaran talking stick pada mata pelajaran sejarah terdapat adanya pengaruh yang signifikan dari perserta didik jika dibandingkan dengan peserta didik yang diberi perlakuan dengan model pembelajaran konvensional. Hal tersebut dapat dilihat bahwa rata-rata dari hasil belajar menggunakan model pembelajaran talking stick sebesar 87,16 sedangkan untuk pembelajaran yang menggunakan model konvensional hanya sebesar 66,85 .

Adanya pengaruh dari penggunaan model talking stick terhadap hasil belajar peserta didik pada mata pelajaran sejarah. Dilihat dari perhitungan uji hipotesis dengan taraf signifikan 0,05 dengan ttabel $=2,002$ dan thitung $=2,107$ maka diperoleh tahitung > ttabel yaitu 2,107>2,002. Hal tersebut berarti hipotesis diterima sehingga menyatakan bahwa terdapat pengaruh model pembelajaran talking stick terhadap hasil belajar peserta didik pada mata pelajaran sejarah kelas X di SMK Grafika Yayasan Lektur.

Penggunaan model pembelajaran talking stick dalam kelas eksperimen membuat peserta didik merasa antusias dan senang ketika belajar dengan model talking stick karena model pembelajaran ini berbeda dengan model pembelajaran yang sebelumnya yang hanya dengan cara ceramah dan tanya jawab. Jika dilihat 
dari kedua model tersebut bahwa dengan model pembelajaran talking stick ini mempunyai perubahan terhadap hasil belajar peseta didik.

\section{Daftar Pustaka}

Agung, L., Wahyuni, S. (2013). Perencanaan Pembelajaran Sejarah. Yogyakarta: Ombak.

Amir, A. (2016). Pembelajaran Matematika Dengan Menggunakan Model Kooperatif Tipe Talking Stick. Jurnal Logaritma, $4(1), 1-16$.

Arianto, A., Iriani, T., Arthur, R. (2019). Hubungan Komunikasi Instruksional Dengan Hasil Belajar Ilmu Ukur Tanah Di Smk Negeri 1 Jakarta. Jurnal Pendidikan Teknik Sipil, 8(1), 31-39.

Creswell, J. (2009). Research Design Pendekatan Kualitatif, Kuantitatif, dan Mixed. Yogyakarta: Pustaka Pelajar

Dimyati dan Mudjiono. (2006). Belajar dan Pembelajaran. Jakarta: Rineka Cipta.

Distya, M. (2015). Penerapan Model Pembelajaran Talking Stick Untuk Meningkatkan Keaktifan Dan Hasil Belajar Siswa Mata Pelajaran TIK Siswa Kelas VII SMP N 1 Kandeman

Hanafy, M.S. (2014). Konsep Belajar dan Pembelajaran. Jurnal Lentera Pendidikan, 17(1), 66-79.

Harapah, H.H., Panjaitan, A.M. (2019). Penerapan Model Pembelajaran Kooperatif Tipe Talking Stick Terhadap Kemampuan Berfikir Kreatif Matematika Siswa Di Smp Negeri 11 Padangsidimpuan. Jurnal Penelitian dan Pembelajaran MIPA, 4(1), 10-18.

Hartanto, S., Sriyani. (2016). Pengaruh Penerapan Model Talking Stick Terhadap Hasil Belajar Matematika Siswa Kelas VIII SMP Negeri 11 Batam. Jurnal Pythagoras, 5(1), 12-19.

Imanita, M. (2014). Pengaruh Metode Pembelajaran dan Kecerdasan Interpersonal Terhadap Hasil Belajar Sejarah Siswa SMA. Jurnal Pendidikan Sejarah, 3(1), 45-54.

Jamiah, R., Surya, E. (2016). Pengaruh Model Pembelajaran Talking Stick Dengan Metode Math Magic Terhadap Hasil Belajar Matematika Pada Pokok Bahasa
Kubus Dan Balok Di Kelas V Sd Negeri 200211 Padang Sidimpuan. Jurnal Axiom, 5(2), 244-255.

Jumardi. (2014). Pengaruh Pendekatan Pembelajaran dan gaya belajar terhadap hasil belajar sejarah siswa. Jurnal Pendidikan Sejarah, 3(1), 1-12.

Kadir, A. (2013). Konsep Pembelajaran Kontekstual Di Sekolah. Jurnal Dinamika Ilmu, 13(3), 17-38.

Kuntowijoyo. (2013). Pengantar Ilmu Sejarah. Yogyakarta: Tiara Wacana.

Lefudin. (2017). Belajar dan pembelajaran dilengkapi dengan model pembelajaran, strategi pembelajaran, pendekatan pembelajaran dan metode pembelajaran. Yogyakarta: Budi Utama.

Lidia, W., Hairunisya, N., Sujai, I.S. (2018). Pengaruh model talking stick terhadap hasil belajar IPS. Jurnal Teori dan Praksis Pembelajaran IPS, 3(2), 81-87.

Lisjayanti, N.P. (2014). Pengaruh Model Pembelajaran Kooperatif Talking Stick Berbantuan Media Gambar Terhadap Hasil Belajar Ipa Siswa Kelas V Sd Gugus 4 Baturiti. E-journal PGSD Universitas Pendidikan Ganesha, 2(1).

Mardiana, S., Arapu, L. (2015). Pengaruh Model Pembelajaran Talking Stick Terhadap Hasil Belajar Matematika Siswa Kelas Viii Smp Negeri 15 Kendari Pada Materi Lingkaran. Jurnal Penelitian Pendidikan Matematika, 3(3), 125-138.

Matondang, Z. (2009) . Validitas dan Reliabilitas Suatu Instrumen Penelitian. Jurnal Tabularasa PPS Unimed, 6(1), 87-97.

Ngalimun. (2017). Strategi Pendidikan. Yogyakarta: Parama Ilmu.

Pane, A., Dasopang, M.D. (2017). Belajar dan Pembelajaran. Jurnal Kajian Ilmu-Ilmu Keislaman, 3(2), 333-352.

Purnomo, E. (2016). Dasar-Dasar dan Perancangan Evaluasi pembelajaran. Yogyakarta: Media Akademi.

Puspitawangi, K.R., Wibawa, I.M.C,. Pudjwan, K. (2016). Pengaruh Model Pembelajaran Kooperatif Tipe Talking Stick Berbantuan Media Audio Terhadap Hasil Belajar IPS Siswa. E- 
journal PGSD Universitas Pendidikan Ganesha, 4(1), 1-12.

Putra, B. (2019). Pengaruh model pembelajaran kooperatif tipe student teams achievement divison (STAD) terhadap kompetensi belajar siswa ranah kognitif. Journal On Education, 1(4), 783-788.

Putri, A.I.K.D., Prihandono. T., Putra, P.D.A. (2017). Penerapan Model Pembelajaran Talking Stick Disertai Metode Demonstrasi Berbantuan Media Kokami Mata Pelajaran IPA Di SMP. Jurnal Pembelajaran Fisika, 5(4), 321-328.

Putri, S.R., Wahyuni, S., Suharso, P. (2017). Penggunaan Media Pembelajaran Edmodo Untuk Meningkatkan Aktivitas Dan Hasil Belajar Siswa Kelas X Pemasaran Di Smk Negeri 1 Jember Tahun Ajaran 2016/2017. Jurnal Pendidikan Ekonomi, 11(1), 111-116.

Ridia, R. (2016). Pembelajaran Menulis Puisi Lama Dan Puisi Baru Pada Siswa Kelas VII SMP Perintis 1 Bandar Lampung Tahun Pelajaran 2015/2016.

Rusman. (2016). Model-Model Pembelajaran: Mengembangkan Profesionalisme Guru. Jakarta: Rajawali Pers.

Safitri, I., Ibrahim, M.M., Nursalam. (2018). Pengaruh Penerapan Model Talking Stick Dengan Bantuan Media Choose Number Terhadap Hasil Belajar Biologi Di Smp Negeri 3 Sungguminasa Kabupaten Gowa. Jurnal Biotik, 3(1), 131-144.

Sayono, Joko. (2013). Pembelajaran Sejarah Di Sekolah: Dari Pragmatis Ke Idealis. Jurnal Sejarah dan Budaya, 7(1), 9-17.

Siregar, S. (2015). Pengaruh model pembelajaran talking stick terhadap hasil belajar dan aktivitas visual siswa pada konsep sistem indra. Jurnal Biotik, 3(2), 100-106.

Sirnayatin, T.A. (2017). Membangun Karakter Bangsa Melalui Pembelajaran Sejarah. Jurnal SAP, 1(3), 312-321.

Sugiyono. (2014). Metode Penelitian Kuantitaif, Kualitatif, dan R\&D. Bandung: Alfabeta. (2015). Metode Penelitian Pendidikan (Pendekatan Kuantitatif, Kualitatif, dan R\&D). Bandung: Alfabeta.
(2017). Statistika Untuk Penelitian. Bandung: Alfabeta.

Sulastri., Imran., Firmansyah. A. (Tanpa Tahun). Meningkatkan hasil belajar siswa melalui strategi pembelajaran berbasis masalah pada mata pelajaran IPS di kelas V SDN 2 limbo makmur kecamatan bumi raya. Jurnal Kreatif Tadulako Online, 3(1), 90103.

Sumantri, M.S. (2016). Strategi Pembelajaran: Teori dan Praktik di Tingkat Pendidikan Dasar. Jakarta: Rajawali Pers.

Sunhaji. (2016). Pengaruh Model Pembelajaran Kooperatif Tipe Talking Stick Terhadap Hasil Belajar Siswa Kelas I Mata Pelajaran Tematik Di MI Salafiyah Syafi'iyah II Klinterejo Nojokerto. Jurnal Program Studi PGMI, 3(2), 99-105.

Susanto, A. (2016). Teori Belajar dan Pembelajaran Di Sekolah Dasar. Jakarta: Kencana.

Suyanto. (2018). Penerapan model pembelajaran Snowball throwing berbantu media gambar untuk meningkatkan aktivitas dan hasil belajar materi pesawat sederhana pada siswa kelas V SD 8 gondosari. Jurnal Prakarsa Pedagogi, 1(2), 196-204.

Tanjung, S. (2015). Pengaruh Media Pembelajaran dan Gaya Kognitif Terhadap Hasil Belajar Sejarah. Jurnal Paramita, 25(2), 261-271.

Utama, I.G.M.P., Dibia, I.K., Renda, T. (2019). Pengaruh Model Talking Stick terhadap Hasil Belajar PKn pada Siswa Kelas V Semester II SD di Gugus I Kecamatan Gerokgak Tahun Pelajaran 2017/2018. Jurnal Pedagogi dan Pembelajaran, 2(1), 123-130.

Wulandari, D.F. (2016). Penerapan Metode Talking Stick Untuk Meningkatkan Keaktifan Dan Hasil Belajar Siswa Pada Mata Pelajaran Boga Dasar Di SMKN 3 Magelang.

Zahro, M., Sumardi., Marjono. (2017). The Implementation Of The Character Education In History Teaching. Jurnal Historica, 1(1), 1-11. 